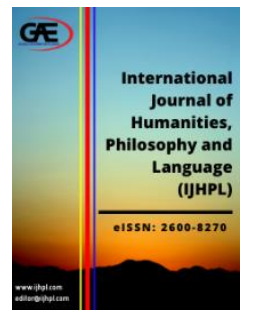

International Journal of Humanities, Philosophy and Language (IJHPL)

Journal Website: http://ijhpl.com/ eISSN: 2600-8270

\title{
CHALLENGES OF TAKING MALAY LANGUAGE COMMUNICATION COURSE AMONG INTERNATIONAL STUDENTS IN TERTIARY LEVEL OF STUDIES
}

\author{
Suhaila Ngadiron ${ }^{1}$, Azureen Abd Aziz ${ }^{2}$, Nurien Hidayu Muhamad Rusly ${ }^{3}$ \\ 1 Centre of Liberal Arts and Languages, INTI International University, Malaysia. \\ Email: suhaila.ngadiron@ newinti.edu.my \\ 2 Centre of Liberal Arts and Languages, INTI International University, Malaysia. \\ Email: azureen.abdaziz@newinti.edu.my \\ 3 Centre of Liberal Arts and Languages, INTI International University, Malaysia. \\ Email: nurien.rusly@newinti.edu.my
}

\section{Article Info:}

\section{Article history:}

Received date:23.12.2019

Revised date: 29.12 .2019

Accepted date: 21.01.2020

Published date: 10.03.2020

\section{To cite this document:}

Ngadiron, S., Abd Aziz, A., \& Rusly, N. H. M. (2020). Challenges of Taking Malay Language Communication Course among International Students in Tertiary Level of Studies. International Journal of Humanities, Philosophy and Language, 3 (9), 01-19.

DOI: $10.35631 /$ IJHPL.39001.

\begin{abstract}
:
This study was conducted to identify the challenges faced by tertiary students to converse and communicate using the Malay language in their tertiary learning. Data obtained were based on a few observations conducted on 100 students who took the Malay Language Communication course. Students were asked to video-record their daily communication with local students using Malay language. Then, the data obtained from the observations would be presented via presentation in class. Based on the feedback received, there are three major challenges faced by these international students that include; mother tongue destruction, student attitude, and environmental issues. Few recommendations are presented based on the research findings.
\end{abstract}

Keywords:

Malay Language, Challenges, International Students, Converse and Communicate

\section{Introduction}

Malay is the official language and communication medium used among the communities in Malaysia. The language also serves as a medium for knowledge transfer as gazetted in the Education Act 1961. However, at the start of 1996, following the rise in the number of international students enrolling in higher education institutions in Malaysia, the Ministry of Education Malaysia amended the act to the Education Act 1996 and the Private Higher Education Act 1996 (Isahak, 1999). The aim was to not only elevate the Malay language, but 
also to strengthen the Malay language education system especially at higher education institutions in Malaysia.

As the Malay language subject has been introduced to international students who are enrolled in higher education institutions in Malaysia, they are required to take up the course during their study period, and they must pass the course as a pre-requisite to their education (Awang Sariyan, 2006). The course is dubbed Bahasa Melayu Komunikasi. The course structure emphasises on communication using simple language orally or in written form. Teaching and learning will be implemented in the form of lectures, tutorials, assignments and experiential learning in and out of the classroom. The aim of the course is to empower international students to master the foundation of utilising the Malay language, so as to allow them to interact with Malaysian citizens, especially the Malays. The Malaysian Qualifications Agency (MQA) has outlined the learning outcomes to be achieved in the Bahasa Melayu Komunikasi course.

The course has clearly displayed a broad range of learning outcomes to enable international students to understand and master the fundamentals of the Malay language well. It is important to note that the learning of the Malay language is not to develop fluency among the international students similar to the native speakers, but emphasises on the capability to understand the language to enable the students to listen and understand speech as well as the written form, in addition to communicating simple messages. At the same time, it is hoped that the students will be able to speak well in a simple manner to interact with the Malaysian community. However, there exist a few issues commonly mentioned and do arise when the issue of Malay language learning is discussed among international students. As communicative skills are vital, this research is carried out to identify the challenges in speaking in Malay faced by international students enrolled in the MPU3143 course.

\section{Problem Statement}

This research is carried out by fully focusing on general communication as the course structure of Bahasa Melayu Komunikasi emphasises this skill. The reason for this is that speaking skill is fundamental and important in language teaching and learning process (Siti Saniah, 2013). Fa'izah, Zamri and Mohamed Amin (2009) observed international students of Universiti Kebangsaan Malaysia and found that students who are learning Malay were unable to grasp speaking skills well. The research conducted by Ab. Razak and Muhammad Saiful Haq (2011) on the mastery of foreign languages among students generally shows students do not obtain or barely grasp fundamentals of the targeted language within a given period. This scenario must be resolved immediately as many international students are inbound for study in Malaysia. Statistics by the Ministry of Higher Education shows that on January 2017, Malaysia recorded and influx of 157,000 international students, but the number increased towards the end of December 2017 which recorded 177,000 students (Ministry of Higher Education Malaysia Statistics, 2017).

A research conducted by Bailey (2015) found that students learning a language felt the speaking component of the target language presents much of a challenge as compared to other skills in the target language. This is a fact as when one speaks, one is unable to edit or retract what has been said as speaking happens in real time (Zawawi, Ab Halim, Nik Mohd Rahimi \& Mohd Ala-uddin, 2011). Brown (2001) argued that the success in mastering any language is viewed on how the language is spoken. Thus, the issue faced by international students focusing on their speaking capabilities must be observed and understood so the ability to speak, which is the main skill in human interaction can be resolved quickly (Siti Saniah, 2013). 


\section{Research Question}

What are the difficulties faced and shortcomings possessed by international students in obtaining speaking mastery in the Malay language?

\section{Objective of Study}

To identify the difficulties faced and shortcomings possessed by international students in obtaining speaking mastery in the Malay language.

\section{Purpose of Study}

The purpose of this study is to observe the challenges faced by international students to speak the Malay language well with emphasis on the issues as well as shortcomings faced in mastering speaking mastery in the Malay language. Once the issues and shortcomings are identified, the researcher intends to provide suitable recommendations to improve the speaking mastery in line with the data acquired.

\section{Methodology}

The methodology applied is a qualitative study. This qualitative approach is a research procedure generating descriptive data such as written or spoken comments based on the informant observed. This approach is a research approach that obtains understanding based on an occurring phenomenon (Afriani, 2009). Azizah (2010) argued that the qualitative methodology outlines non-numerical findings and observation even though there are findings expressed in statistics. Majority of the study outlines findings, interpretations or meaning in the communication process. A qualitative researcher is the instrument of study.

In this study, the researcher utilises documental research analysis procedure. According to Jasmi (2012), the documental research analysis method will outline information that is relevant to the question and issue studied. In addition, documents are an easily accessible resource to the research as the information is on-hand and cannot be falsified. To obtain data required, 100 student assignments were selected from various fields of study programmes. The students were assigned to record an everyday conversation with other local students. The topic is not specified, and the length of the video must not exceed 3 minutes. The recorded conversation will then be uploaded onto their individual Blackboard Accounts and will be presented in class to be analysed. This is in line with Siti Saniah (2013) who argued that the learning process of the Malay language must be conducted outside of the classroom to allow students to speak in an actual speaking environment. In addition, the use of the language during the students' conversation with their course mates, lecturers and during the presentation in the class will also be analysed. The students come from various countries which includes Fiji, China, Bangladesh, Egypt, Korea and Oman.

\section{Research Finding}

Analysis conducted on 100 respondents show various issues that hinder their capability to speak in Malay. The research results outline three main factors which are categorised as mother tongue interference, student attitude and environmental factors.

The mother tongue interference factor is the main constraint faced. The challenge observed is issues with pronunciation. As an example, a Chinese nationality student will take time to pronounce each syllable in a word such as 'be_re_nang'. The student also finds it difficult to pronounce words with the letters $/ \mathrm{b} /$ and $/ \mathrm{p} /$ as well as $/ \mathrm{d} /$ and $/ \mathrm{t} /$ (Awang Sariyan, 2011). An example would be the greeting 'Selamat pagi' which will be pronounced as 'Selamad bagi' 
due to the negligible difference between the $/ \mathrm{b} /$ and $/ \mathrm{p} /$ sounds in their own native language. The issue arises as the students are influenced by the own national language, which is Mandarin, which has differences in a number of aspects if compared to the Malay language. Awang Sariyan's (2011) argument states that the Chinese students face a major difficulty in pronouncing the vibrating $/ \mathrm{r} /$ as the sound is very minimal in their mother tongue while it is vibrating sound feature in Malay. The research also supports the study conducted by Abdull Sukor, Nuraini, Mohd Izam and Mohd Hasani (2011) on the Orang Asli students in Malay language literacy. The research shows that Orang Asli students constantly encounter mother tongue interference in speech. Due to this reason, teaching of speaking skills become difficult as it is challenging to understand the pronunciation of words and their own fear of making mistakes.

The next constraint identified is the student's attitude. The student's preference to be within a group of similar native speakers results in the opinion that they do not need to communicate in Malay. In-class observation highlights that their association being slightly limited. The students prefer to mingle in their own community. Students from Middle Eastern countries will associate only with those from similar nations. They will not co-mingle with students from the Malay Archipelago such as Brunei, Singapore or Indonesia who clearly have better understanding and speaking capabilities in the Malay language. They will always be selective of group members who are from their own country. This situation further complicates their ability to learn and speak using the Malay language. According to Siti Saniah (2013), the association with native speakers is crucial to allow any individual to become competent speakers of the language. Association between international students with more experienced speakers of the Malay language is beneficial to the international students themselves. This association is suggested to bring about a positive outcome as stated by Holmes (2003) in his research on cooperative learning in university. His research identified that cooperative learning among students who are experienced with those of less experience will bring about a positive impact in learning. In context of this study, interaction between experienced Malay speakers and inexperienced international students will be beneficial to the latter.

The final factor identified which causes hindrance to international students to speak using the Malay language is their own environment. An environment which does not favour the Malay language hinders the students learning process to speak in Malay. This situation arises where the immediate community uses English to communicate and application of social dialects which are difficult to be understood by the students such as mixed language, slangs, colloquial languages and others. Analysis of the presentation videos shows that the locals (e.g a night market situation) refuse to speak in Malay with the students even though effort was given by them to speak in Malay. This particular environment extremely hinders their speech in Malay. The study also supports the argument by Siti Saniah (2012) who states that an unsupportive learning environment hinders mastery of the national language of Malaysia which is Malay among the international students. This phenomenon further amplifies the reason for comfort among international students to use English in lieu of Malay when communicating with Malaysians. Thus, the Malay language could not be used practically in an actual environment.

\section{Discussion}

Based on the factors identified, how would international students taking up the Malay language subject be assisted to enhance the learning of the language to allow them to obtain mastery in the Malay language? The researcher is of the opinion that a more practical approach to learning must be introduced to assist these students to learn the language is faster, simpler and effective 
method. This is a crucial though as the failure among international students in the Malay language course will affect their education pathway and academic achievements as a whole.

A method that can be utilised is a learning approach using planned and student-cantered language learning strategies (LLS) which is necessary to be practised as an alternative to assist in resolving the issue entirely and improves the learning process entirely. A number of LLS studies have succeeded in proving that LLS is a critical element in understanding the process and method of how second/foreign language is acquired (Ellis, 1994). LLS is divided into three main constructs which are in-class LLS, outside-classroom LLS and examination LLS (Noor Zuhidayah Muhd Zulkifli, Siti Saniah, 2016). In-class LLS according to Mohamed Amin Embi (2000) is a strategy used by students in the class which includes language use in class, social education in class in handling new words and physical structures in each class (Kamarul Shukri Mat The \& Mohamed Amin Embi, 2010). LLS outside of the classroom refers to strategies utilised by students to acquire the Malay language outside of a classroom environment which includes focused learning, use of media, social education outside of class and pre-classroom preparation (Kamarul Shukri Mat Teh \& Mohamed Amin Embi, 2010). Examination LLS is the preparation undertaken by students to sit for their examination. Analysis shows a positive effect of LLS on the achievement, learning and acquisition of the language by the students. A number of LLS identified that high-achieving students of the language are more skilled and utilises LLS to a larger extent in learning the language compared to students who are weaker in the language (Bruen, 2001).

In addition, the researcher is of the opinion that the short teaching and learning duration has become one of the factors that hinder students to speak in Malay. Majority of Malay language courses for international students are conducted for only 2 hours a week. The duration is too short as it involves only lectures and no tutorial sessions with the teacher (Awang Sariyan, 2011). Thus, it is has become a challenge for teachers to deliver the education of a foreign language in a classroom disconnected from the native environment of the language itself. According to Asmah (2003), teachers must create an artificial environment for the language to be utilised. In this situation, university programmes must be organised to allow more time for the teaching and learning of the Malay language, conduct homestay activities, foster family visits and others to encourage and train the students to speak in Malay. In addition, interesting and fun activities such as singing competitions, poetry recitals and movie show in Malay should be increased.

\section{Conclusion}

In summary, Malay language learning is not difficult if the students receive support and encouragement from their friends, lecturers as well as their immediate community. In time, the speaking capabilities of these students can be improved by reading books or materials in Malay, listening and watching Malay programmes, as well as being actively involved in learning activities in or out of the classroom which involves the local community. Currently, more international students are opting for Malaysia to further their studies in either the government or private education institutions. We should embrace this opportunity to market the Malay language to the international student community studying in this country. An organised and effective teaching and learning plan must be carried out as it does not only uplift the Malay language, but to also introduce our national language to the world. 


\section{References}

Abdull Sukor Shaari, Nuraini Yusuff, Mohd Izam Ghazali \& Mohd Hasani Zali. (2011). Kanak-kanak minority Orang Asli di Malaysia: Menggapai literasi bahasa Melayu Jurnal Pendidikan Bahasa Melayu, 1(2): 59-70.

Ab. Razak \& Muhammad Saiful Haq. (2011). Tahap penguasaan bahasa Melayu pelajar Islamic Santitham Faoundation School (ISFS). Jurnal Pengajian Melayu, 11: 18-44.

Afriani. (2009). Metode Penelitian Kualitatif. http://www.penalaran-unm.org.

Asmah Hj. Omar. (2003). Pengajaran bahasa Melayu untuk penutur asing: Kaedah dan prinsip. Kuala Lumpur: Dewan Bahasa dan Pustaka.

Awang Sariyan. (2006). Pengajaran bahasa Melayu kepada penutur asing: Matlamat dan pertimbangan strategi. Jurnal Persatuan Linguistik, 7: 1-15.

Awang Sariyan. (2011). Pendidikan bahasa Melayu dalam pembentukan jati diri bangsa: Pengajaran seni bahasa untk penghayatan bahasa kepada pelajar asing. Persatuan Pendidikan Bahasa Melayu Malaysia, Jabatan Pendidikan Negeri Terengganu dan Dewan Bahasa dan Pustaka Wilayah Timur pada 14-16 Mac 2011.

Azizah Hamzah. (2010). Kaedah kualitatif dalam penyelidikan sosiobudaya. Jurnal Pengajian Media Malaysia, 6 (1).

Bailey, K. M. (2005). Practical English language teaching: Speaking. New York: McGrawHill.

Brown, H. D. (2001). Teaching by principles: An Interactive Approach to language pedagogy. New York: Longman.

Bruen, J. (2001). Strategies for success: Profiling the effective learner of German. Foreign Language Annals, 34: 216-225.

Ellis, R. (1994). The study of second language acquisition. Oxford: Oxford University Press.

Fa'izah Abd. Manan, Zamri Mahamod \& Mohamed Amin Embi. (2009). Penyelidikan strategi pembelajaran bahasa Melayu sebagai bahasa asing dalam kalangan pelajar luar negara. Prosiding Seminar Pendidikan Serantau Ke-4 2009, 259-268.

Holmes, R. (2003). Collaborative projects: A study of paired work in a Malaysian University. Innovation in Education and Teaching International, 40 (3): 254-259.

Isahak Haron. (1999). Penggunaan dan penguasaan bahasa Melayu dalam pendidikan tinggi di Malaysia: Cabaran dalam alaf baru. Dewan Bahasa, 43(9): 798-812.

Jasmi. K. A. (2012). Metodologi pengumpulan data dalam penyelidikan kualitatif in Kursus Penyelidikan Kualitatif Siri 12012 at Puteri Resort Melaka 0n 28-29 Mac 2012. Organized by Institut Pendidikan Guru Malaysia Kampus Temenggong Ibrahim, Jalan Datin Halimah, Johor.

Kamarul Shukri Mat Teh \& Mohamed Amin Embi. (2010). Strategi Pembelajaran Bahasa. Universiti Malaya. Kuala Lumpur.

Mohamed Amin Embi. (2000). Language Learning Strategies: A Malaysian Context. Bangi: UKM.

Naffi Mat. (2012). Memartabatkan bahasa Melayu: Pengajaran dan pembelajaran. Tanjung Malim: Penerbit Universiti Pendidikan Sultan Idris.

Noor Zuhidayah Muhd Zulkifli, Siti Saniah Abu Bakar. (2016). Strategi pembelajaran bahasa Melayu dalam kalangan pelajar di Jerman. Jurnal Kurikulum \& Pengajaran Asia Pasifik, 4(2): 10-19.

Perangkaan Kementerian Pengajian Tinggi Malaysia. (2017). (Atas talian). Muat turun 23 Ogos 2019 dari. http://www.mohe.gov.my/web statistik/index.htm.

Siti Saniah Abu Bakar. (2012). Pandangan pelajar dalam tugasan drama yang dijalankan semasa mempelajari bahasa Melayu. Dlm. Mahzan Arshad, Idris Mohd Radzi \& Naffi Mat. (2012). Memartabatkan Bahasa Melayu: Pengajaran dan pembelajaran. Tanjung Malim: Penerbit Universiti Pendidikan Sultan Idris. 
Siti Saniah Abu Bakar. (2013). Kekangan pelajar asing dalam menggunakan kemahiran bertutur bahasa Melayu. Jurnal Pendidikan Bahasa Melayu, 3(1): 52-62.

Zawawi Ismail, Ab Halim Tamuri, Nik Mohd Rahimi Nik Yusoff \& Mohd Ala-Uddin Othman. (2011). Teknik pengajaran kemahiran bertutur bahasa Arab di SMKA di Malaysia. Gema Online Journal of Language Studies, 11: 68-82. 